\title{
Regeneration Traits of Four Dominant Species in a Cool-Temperate Conifer-Hardwood Mixed Forest, Northern Japan
}

\author{
Koichi Takahashi ${ }^{1,2 *}$ \\ ${ }^{1}$ Department of Biology, Faculty of Science, Shinshu University, Matsumoto, Japan \\ ${ }^{2}$ Institute of Mountain Science, Shinshu University, Matsumoto, Japan \\ Email: *koichit@shinshu-u.ac.jp
}

How to cite this paper: Takahashi, K. (2017) Regeneration Traits of Four Dominant Species in a Cool-Temperate Conifer-Hardwood Mixed Forest, Northern Japan. American Journal of Plant Sciences, 8, 3313-3323.

https://doi.org/10.4236/ajps.2017.813223

Received: November 6, 2017

Accepted: December 8, 2017

Published: December 11, 2017

Copyright $\odot 2017$ by author and Scientific Research Publishing Inc. This work is licensed under the Creative Commons Attribution International License (CC BY 4.0).

http://creativecommons.org/licenses/by/4.0/

\begin{abstract}
Regeneration traits of four dominant species were studied during a decade in a cool-temperate conifer-hardwood mixed forest, northern Japan. Dominant species were three canopy species (Tilia japonica, Acer mono and Abies sachalinensis) and a subcanopy species Prunus ssiori. Regeneration traits differed among the four dominant species. The regeneration of a conifer Abies sachalinensis largely depends on major disturbances because its size structure was a bell-shaped pattern. The growth rate of the sub-canopy species Prunus ssiori increased faster with tree size than the other three species, and therefore, this species can reach reproductive stage faster. Although the number of recruits of Tilia japonica was less than the other three dominant species, about one-fourth of Tilia japonica regenerated by the sprouts. Thus, vegetative reproduction is important for the regeneration of Tilia japonica. On the contrary, many recruits were observed in Acer mono, and its recruits and saplings concentrated in canopy gaps, suggesting that the regeneration of Acer mono restricted to canopy gaps. Thus, clear differences in the regeneration traits were recognized in the four dominant species. This study suggests that the species-specific regeneration traits contribute to the species coexistence of the four dominant species through different regeneration niches.
\end{abstract}

\section{Keywords}

Canopy Gaps, Competition, Disturbances, Growth, Sprouts

\section{Introduction}

Conifer-hardwood mixed forests widely distribute in the middle latitude of 
Northern Hemisphere [1] [2] [3]. Forest structure and dynamics of this type of forest ecosystem have often been examined in relation to major disturbances [4] [5]. For example, several researchers have shown discontinuous age and size distributions, and discussed the importance of major disturbances for species coexistence [6] [7] [8] [9]. However, all species in a conifer-hardwood mixed forest do not always depend on major disturbances for their regeneration. Return times for major disturbances are unpredictable, and sometimes exceed more than a millennium [10] [11] [12]. Therefore, coexistence mechanism in conifer-hardwood mixed forests cannot be adequately explained by major disturbances alone.

In equilibrium conditions without major disturbances, tree competition is important role in structuring force of community through interspecific differences in density-dependent demographic rates (recruitment, growth and mortality), i.e., higher growth and recruitment rates and lower mortality in less crowded conditions, and vice versa in more crowded conditions [13] [14] [15] [16] [17]. Kobe et al. [18] has examined the interspecific variation in sapling mortality in relation to the growth rate, and showed a positive correlation between growth rate in high light conditions and mortality in low light conditions. Thus, the potential growth rate of shade-intolerant species is high, but their regeneration is often restricted to canopy gaps [19] [20]. Therefore, tree competition (or canopy cover) largely influences the regeneration dynamics through the density-dependent demographic rates.

A conifer Abies sachalinensis Masters and three deciduous hardwood species Acer mono Maxim., Tilia japonica (Miq.) Simonkai and Prunus ssiori Fr. Schm. dominate in a cool-temperate conifer-hardwood mixed forest in northern Japan [21]. This study analyzes the population structure and dynamics of the four most dominant species based on size structure, gap regeneration and tree competition by using the 10-year data of permanent plots to examine how regeneration traits differ among the four most dominant species.

\section{Materials and Methods}

\subsection{Study Site}

This study was conducted in a cool-temperate conifer-hardwood mixed forest in Hokkaido, northern Japan $\left(43^{\circ} 1^{\prime} \mathrm{N}, 143^{\circ} 38^{\prime} \mathrm{E}, 200 \mathrm{~m}\right.$ above sea level). Annual precipitation, recorded at Honbetsu Weather Station (ca. $10 \mathrm{~km}$ from the study site), was $837 \mathrm{~mm}$ during 1993 to 2004. Mean monthly temperatures of the coldest month of January and the hottest month of August were $-8.7^{\circ} \mathrm{C}$ and $19.4^{\circ} \mathrm{C}$, respectively, with $6.2^{\circ} \mathrm{C}$ of annual mean temperature. Forest floor was patchily covered with Sasa nipponica Makino. The forest was well reserved, and therefore, there were no anthropogenic effects on the vegetation. Takahashi [21] described the vegetation and stand structure of this forest.

\subsection{Field Methods}

Three plots were established in a conifer-hardwood mixed forest in 1994. Plot 
size was $40 \times 100 \mathrm{~m}, 30 \times 50 \mathrm{~m}$ and $60 \times 100 \mathrm{~m}$ (total $1.15 \mathrm{ha}$ ). Each plot was sub-divided into $5 \times 5 \mathrm{~m}$ quadrats. I determined canopy gaps in each $5 \times 5 \mathrm{~m}$ quadrat in 1994; quadrats with less than $50 \%$ of canopy coverage were defined as canopy gaps in this study. All trees $\geq 1.5 \mathrm{~cm}$ in diameter at breast height (DBH) were tagged, and their DBH was measured in 1994. Census was conducted also in 1995, 1996, 1998, 1999 and 2004. Dead trees and newly recruited trees, growing to $\geq 1.5 \mathrm{~cm} \mathrm{DBH}$, during successive censuses were recorded.

\subsection{Data Analyses}

The population dynamics of the four dominant species (Abies sachalinensis, Acer mono, Prunus ssiori and Tilia japonica) was analyzed. I analyzed the effects of tree competition on $\mathrm{DBH}$ growth rates of target trees, applying the following equation [9] [22] [23] [24] [25] [26],

$$
\mathrm{ADGR}=a_{0}+a_{1} \mathrm{DBH}+a_{2} \mathrm{BA}_{\mathrm{L}}
$$

where ADGR is the absolute diameter growth rate $\left(\mathrm{mm} \cdot \mathrm{year}^{-1}\right)$ of a target tree during 1994 to 2004, and $\mathrm{BA}_{\mathrm{L}}$ is the cumulative basal area $\left(\mathrm{cm}^{2} \cdot \mathrm{m}^{-2}\right)$ of neighboring trees larger than the target tree. Coefficient $a_{0}, a_{1}$ and $a_{2}$ are constants. Coefficient $a_{0}$ is a growth rate at $\mathrm{DBH} 0 \mathrm{~cm}$ without suppression from neighboring trees, $a_{1}$ means the rate of increase of growth rate with increasing $\mathrm{DBH}$, and $a_{2}$ means the rate of decrease of growth rate with increasing neighboring trees if the coefficient is a minus value. These coefficients were compared among the four species to examine the growth traits. Target individual trees were divided into five arbitrary DBH classes chosen to arrange similar vertical strata (1.5 - 4.9, 5.0 - 9.9, 10.0 - 19.9, 20.0 - 39.9, $\geq 40.0 \mathrm{~cm} \mathrm{DBH).} \mathrm{I} \mathrm{defined} \mathrm{the} \mathrm{neighboring} \mathrm{trees}$ if they satisfied the following two conditions: trees belonging to the same or larger size class of the target individual tree because the primary interest of this analysis was to express competition for light; trees in the same $10 \times 10 \mathrm{~m}$ quadrat in which the target tree was located [9] [22] [23] [24] [25] [26]. Local crowding was calculated for each target individual tree. Multiple linear regression analysis was conducted for the ADGR equation. ADGR was ln-transformed before the analysis to improve homoscedasticity.

Tree mortality is a discrete event. A datum can have only the value 0 (live) or 1 (dead). Therefore, I used the logistic equation to model the probability of tree mortality of the four dominant species as:

$$
M=\frac{1}{\left(1+\exp \left(-b^{\prime} X\right)\right) \times t}
$$

where $M$ is the annual mortality during 1994 to 2004 (year ${ }^{-1}$ ), $b^{\prime} X$ is a linear combination of parameter $b$ and independent variable $X$, and $t$ is the observation period ( $t$ years). $M$ ranges between 0 and 1 , so percent mortality ( $\%$ year ${ }^{-1}$ ) can be obtained by multiplying $M$ by 100 . This study examined the effects of $\mathrm{DBH}$, growth rate and competition on the tree mortality. Size-dependent mortality sometimes shows a U-shaped pattern with higher mortality at saplings and large canopy trees because of suppression of saplings by tall canopy trees and because 
of senescence of large canopy trees [26] [27]. Such a U-shaped mortality can be expressed by a quadric function of size. Degree of local crowding by larger neighboring trees on target dead trees can be expressed as the cumulative basal area of neighbors within the same $10 \times 10 \mathrm{~m}$ quadrat in which the target dead tree was located. Several researchers also showed that tree mortality is higher for trees with lower growth rates, and therefore, growth rate can be used as an integrated measure of whole-plant carbon gain [18] [27] [28] [29] [30]. Combining these effects, the hypothesized mortality model is:

$$
M=\frac{1}{\left(1+\exp \left(-\left(b_{0}+b_{1} \mathrm{DBH}+b_{2} \mathrm{DBH}^{2}+b_{3} \mathrm{ADGR}+b_{4} \mathrm{BA}_{\mathrm{L}}\right)\right)\right) \times t}
$$

where coefficient $b_{0}, b_{1}, b_{2}, b_{3}$ and $b_{4}$ are constants, DBH is the initial DBH $(\mathrm{cm})$ in 1994, and $\mathrm{BA}_{\mathrm{L}}$ is the total basal area $\left(\mathrm{cm}^{2} \mathrm{~m}^{-2}\right)$ of larger neighbors than the target dead tree. I estimated the parameters of the logistic equation using maximum likelihood methods. Backward stepwise regression was also used. The criterion for including and removing an independent variable was set as $P=0.1$ [31].

In this paper, two life phases were defined: sapling $(1.5 \leq \mathrm{DBH}<10 \mathrm{~cm})$ and canopy tree $(\mathrm{DBH} \geq 10 \mathrm{~cm})$. To examine the canopy-gap dependency of saplings and recruits (during 1994 to 2004) of the four dominant species, the percentage of gap saplings (or recruits) was determined. Data in 1994 were used for saplings. I conducted a randomization test to determine significant differences in the observed percentage of gap saplings (or recruits) from random distribution. The data set of saplings (or recruits) was re-assorted randomly. I calculated the percentage of gap saplings (or recruits) for 1000 random re-assortment of saplings (or recruits), keeping the spatial distribution of canopy gaps fixed. If the observed percentage of gap saplings (or recruits) fell in either of the $2.5 \%$ tail of the calculated-value-distribution, the observed percentage of gap saplings (or recruits) was assumed to be significantly different from random. This calculation was conducted on the basis of $5 \times 5 \mathrm{~m}$ quadrats.

\section{Results}

Total 30 hardwood species and a conifer Abies sachalinensis, larger than $1.5 \mathrm{~cm}$ $\mathrm{DBH}$, were recorded in the three plots. The four species (Abies sachalinensis, Acer mono, Prunus ssiori and Tilia japonica) occupied $72 \%$ of the total density (1677 trees $\cdot \mathrm{ha}^{-1}$ ) in 1994. The four species varied in the maximum DBH, the DBH frequency distribution and percentage of sprouts. 24.4\% of trunks of Tilia japonica was sprouts, while the percentage of sprouts was only ca. 1\% (Acer mono and Prunus ssiori) and 0\% (Abies sachalinensis). Abies sachalinensis showed a bell-shaped DBH frequency distribution, while the three other species showed L-shaped patterns (Figure 1).

Canopy gaps occupied $19.4 \%$ of the plots in 1994. Saplings and recruits of $A b$ ies sachalinensis significantly distributed more under closed canopies than in canopy gaps (Table 1). The number of recruits was quite low in Prunus ssiori and Tilia japonica during the census period, and their saplings were significantly 

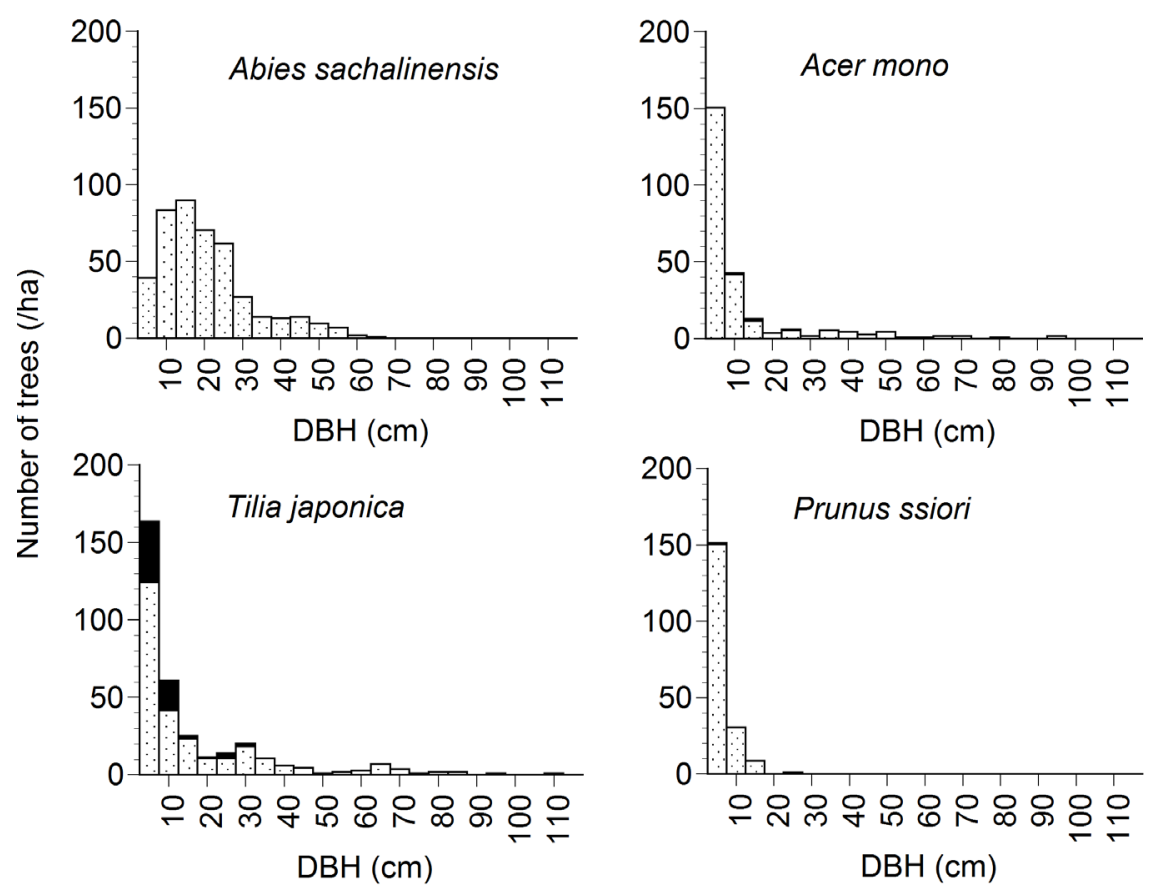

Figure 1. Frequency distributions of DBH for Abies sachalinensis, Acer mono, Tilia japonica and Prunus ssiori in a conifer-hardwood mixed forest, northern Japan, in 1994. Solid bars indicate the number of sprouts.

Table 1. Number of recruits (passing the minimum boundary of $1.5 \mathrm{~cm} \mathrm{DBH}$ during 1994 to 2004$)$ and saplings $(1.5 \leq \mathrm{DBH}<10 \mathrm{~cm})$ in canopy gaps and under closed canopies in a cool-temperate conifer-hardwood mixed forest in northern Japan. The gap area ratio of the plots was $19.4 \%$.

\begin{tabular}{ccccccccc}
\hline \multirow{2}{*}{ Species } & \multicolumn{3}{c}{ Saplings } & & \multicolumn{3}{c}{ Recruits } \\
\cline { 2 - 4 } \cline { 7 - 9 } & Close & Gap & Gap (\%) & & Close & Gap & Gap (\%) \\
\hline Abies sachalinensis & 127 & 14 & $9.9^{--}$ & & 21 & 0 & $0^{--}$ \\
Acer mono & 150 & 72 & $32.4^{++}$ & & 17 & 13 & $43.3^{++}$ \\
Prunus ssiori & 157 & 52 & $24.9^{+}$ & & 3 & 2 & $40.0^{\mathrm{NS}}$ \\
Tilia japonica & 187 & 71 & $27.5^{++}$ & & 4 & 2 & $33.3^{\mathrm{NS}}$ \\
\hline
\end{tabular}

NS: not significant level; ${ }^{+},-5 \%$ positive and negative significant level, respectively; ${ }^{++},{ }^{--}: 1 \%$ positive and negative significant level, respectively, by randomization test.

concentrated in canopy gaps (Table 1). The number of recruits of Acer mono was greater than the other three species, and they were concentrated in canopy gaps (Table 1). Saplings of Acer mono were also more concentrated in canopy gaps than the other three species (Table 1).

Absolute diameter growth rates (ADGR) of the four dominant species increased with DBH (Figure 2), and were decreased by the increase of local crowding of neighbors (Figure 3). The degree of the reduction of ADGR due to the increase of local crowding $\left(a_{2}\right)$ did not differ among the four dominant species because the $95 \%$ confidence interval overlapped among the four species (Figure 3$)$. However, the two other parameters $\left(a_{0}\right.$ and $\left.a_{1}\right)$ varied among the four 

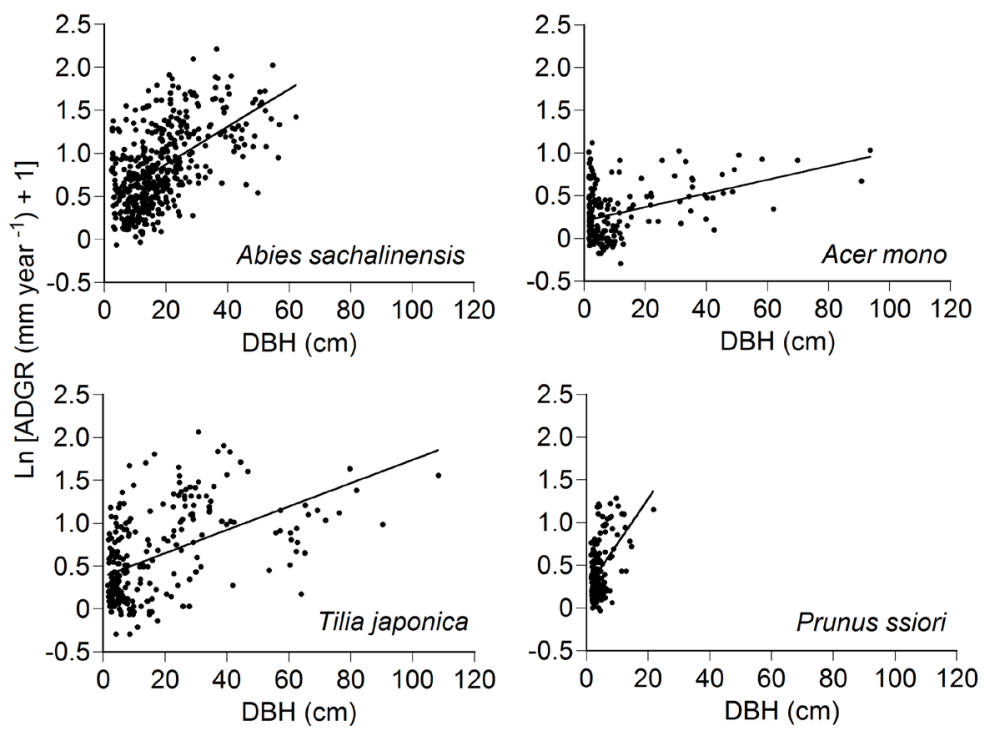

Figure 2. Relationship between $\ln$-transformed ADGR and DBH for the four dominant species. Regression equations are $Y=0.008 X+0.21\left(R^{2}=0.17, n=196\right)$ for Acer mono, $Y$ $=0.022 X+0.43\left(R^{2}=0.31, n=427\right)$ for Abies sachalinensis, $Y=0.053 X+0.22\left(R^{2}=0.24\right.$, $n=158)$ for Prunus ssiori, and $Y=0.014 X+0.38\left(R^{2}=0.26, n=245\right)$ for Tilia japonica, where $Y$ is $\ln$-transformed ADGR $\left(\mathrm{mm} \cdot \mathrm{year}^{-1}+1\right)$ and $X$ is DBH $(\mathrm{cm})$. All regressions are statistically significant $(P<0.001)$.
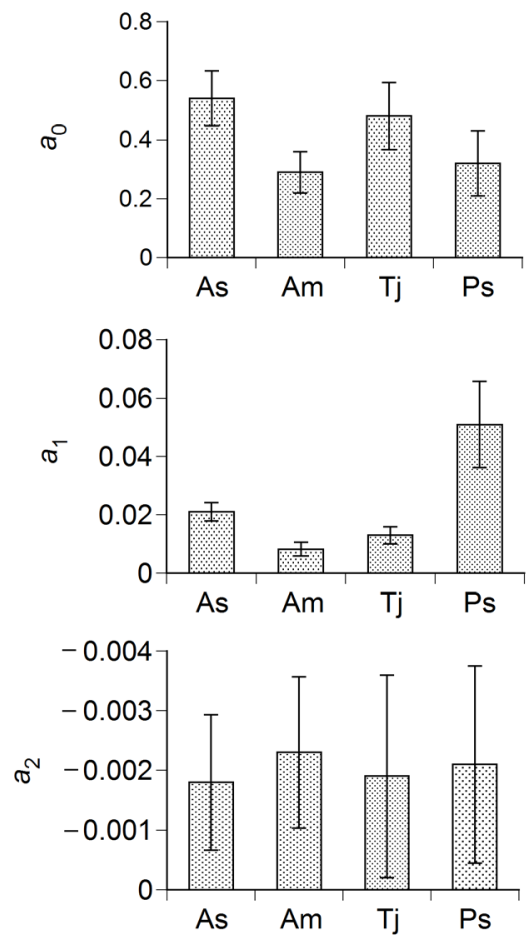

Figure 3. Results of multiple linear regression analysis for the ADGR equation of the four dominant species. A vertical bar indicates a 95 percent confidence interval. All parameters are statistically significant (at least $P<0.05)$. Whole model $R^{2}$ s are $0.32\left(F_{2,424}=103.0\right.$, $P<0.001)$ for Abies sachalinensis (As), $0.24\left(F_{2,189}=31.1, P<0.001\right)$ for Acer mono (Am), $0.26\left(F_{2,154}=28.8, P<0.001\right)$ for Prunus ssiori $(\mathrm{Ps})$ and $0.27\left(F_{2,241}=45.4, P<\right.$ $0.001)$ for Tilia japonica $(\mathrm{Tj})$. 
species. Initial ADGR at DBH $0 \mathrm{~cm}\left(a_{0}\right)$ was lower in Acer mono and Prunus ssiori than Abies sachalinensis and Tilia japonica (Figure 3). The increase of ADGR with DBH $\left(a_{1}\right)$ was greater in the subcanopy Prunus ssiori than the three other canopy species, while that of Acer mono was lowest among the four species (Figure 2 and Figure 3).

Mortality of Acer mono was a U-shaped pattern against DBH, while that of the three other species monotonically decreased with DBH (Figure 4). Although the mortality of the four species showed no relationship with local crowding of larger neighbors $\left(\mathrm{BA}_{\mathrm{L}}\right)$, the mortality of the three species, except for Acer mono, increased with decreasing ADGR (Table 2).

\section{Discussions}

The four dominant species showed different regeneration traits. Abies sachalinensis is shade tolerant species, and forms sapling bank under closed canopy in
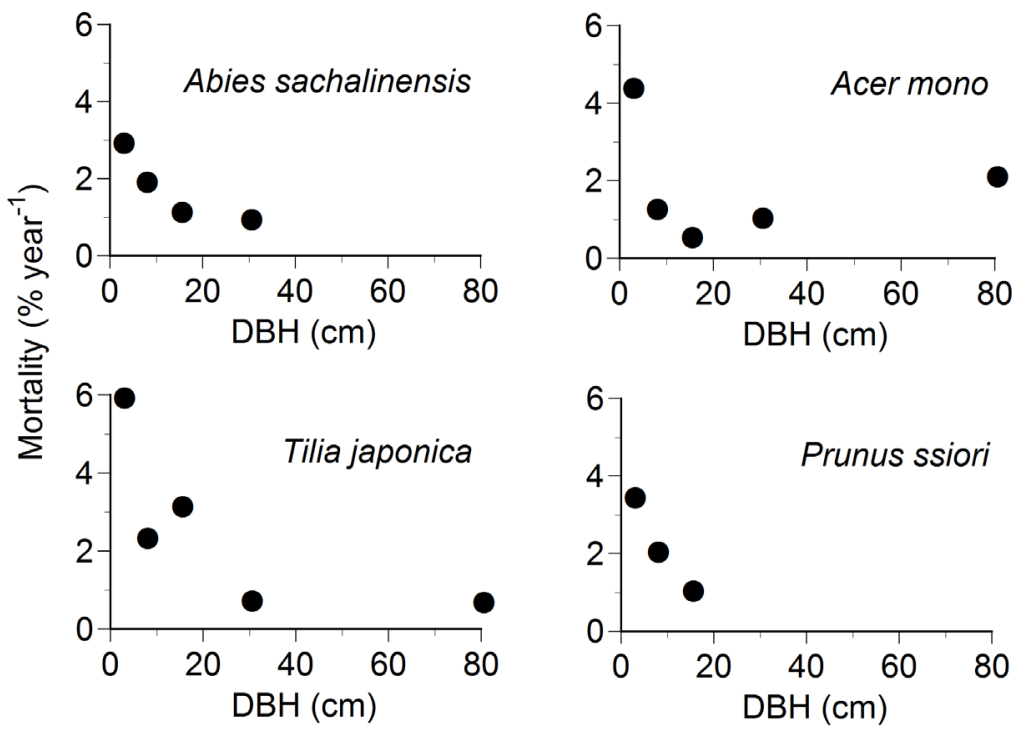

Figure 4. Relationship between mortality and DBH at five DBH classes (1.5 - 4.9, 5.0 $9.9,10.0-19.9,20.0-39.9$ and over $40 \mathrm{~cm}$ ) for the four dominant species.

Table 2. Estimated parameters for the mortality equation of the four dominant species. Parameters selected by the backward stepwise regression were listed.

\begin{tabular}{ccccccc}
\hline Species & $b_{0}$ & $b_{1}$ & $b_{2}$ & $b_{3}$ & $b_{4}$ & $n$ \\
\hline Abies sachalinensis & -1.144 & & $0.00046^{\dagger}$ & $-8.128^{* * *}$ & 498 \\
Acer mono & -0.119 & $-0.144^{* * *}$ & $0.00168^{* * *}$ & & 278 \\
Prunus ssiori & 0.541 & $-0.329^{\dagger}$ & 0.0176 & $-15.667^{* * *}$ & 218 \\
Tilia japonica & 0.969 & $-0.140^{* * *}$ & $0.00157^{* * *}$ & $-14.551^{* * *}$ & 386 \\
\hline
\end{tabular}

$M=\frac{1}{\left(1+\exp \left(-\left(b_{0}+b_{1} \mathrm{DBH}+b_{2} \mathrm{DBH}^{2}+b_{3} \mathrm{ADGR}+b_{4} \mathrm{BA}_{\mathrm{L}}\right)\right)\right) \times t}$, where $b_{0}, b_{1}, b_{2}, b_{2}, b_{3}$ and $b_{4}$ are constants (see text). $\dagger ; P<0.1,{ }^{*} ; P<0.05,{ }^{* *} ; P<0.01,{ }^{* * *} ; P<0.001$. 
subalpine coniferous forests [32]. In this stand, the saplings and recruits of Abies sachalinensis were more concentrated under closed-canopy conditions than in canopy gaps. This suggests that Abies sachalinensis did not depend on canopy gaps for its recruitment. However, the bell-shaped frequency distribution of DBH suggests that many Abies sachalinensis regenerated in a certain period and that regeneration traits of Abies sachalinensis are different between this conifer-hardwood mixed forest and subalpine coniferous forests. It is reported that the discontinuous age structure of Abies sachalinensis in a conifer-hardwood mixed forest in northern Japan [4]. They suggested the importance of catastrophic windblown disturbances such as typhoon on the regeneration of Abies sachalinensis. Thus, Abies sachalinensis can grow and survive under closed-canopy conditions, but sporadic major disturbances accelerate the recruitment in conifer-hardwood forests like this study site.

The increase of ADGR with increasing DBH was greater in the subcanopy species Prunus ssiori than the three other dominant canopy species. Higher growth rate enables Prunus ssiori to reach the reproductive stage faster, compared with the other species. Leaf emergence and leaf fall of Prunus ssiori are considerably earlier than those of other deciduous broad-leaved species [33]. Thus, Prunus ssiori can receive much light before the leaf emergence of the other tall deciduous species, which increases the carbon gain and growth rate of Prunus ssiori in the understory.

Although both Tilia japonica and Acer mono are deciduous canopy tree species, the two species differed in the growth and recruitment rates, and mode of reproduction. The ADGR of Tilia japonica was higher than that of Acer mono at any DBH. This difference is partly due to the difference in wood density. Wood density of Tilia japonica $\left(0.325 \mathrm{~g} \cdot \mathrm{cm}^{-3}\right)$ is much smaller than that of Acer mono $\left(0.632 \mathrm{~g} \cdot \mathrm{cm}^{-3}\right)$ (K. Takahashi, unpublished data). Lighter wood of Tilia japonica would contribute to its higher growth rate per unit dry mass, compared with Acer mono [34] [35]. On the contrary, the number of recruits was less in Tilia japonica than Acer mono (3 versus 24 recruits during 1994 to 2004). However, one-fourth of Tilia japonica regenerated by vegetative reproduction of sprouts. An advantage of sprouting is long-term persistence [36] [37] [38]. Thus, the population of Tilia japonica is maintained by vegetative reproduction.

Many recruits were observed in Acer mono and its recruits and saplings regenerated more in canopy gaps, compared with the other species. However, the gap-dependent regeneration does not mean that Acer mono is a shade-intolerant species. Shade-intolerant species often show a bell-shaped or bimodal size structure, while shade-tolerant species show a L-shaped size structure [39]. The size structure of Acer mono was a typical L-shaped pattern in this stand, indicating a shade-tolerant species. Acer mono increases the height growth rate in small canopy gaps through plastic changes of crown architecture [40], suggesting that Acer mono is a small-gap specialist.

The four dominant species showed species-specific regeneration strategies, 
i.e., disturbance-dependent regeneration (Abies sachalinensis), fast growth rate (Prunus ssiori), vegetative reproduction (Tilia japonica), and regeneration in canopy gaps (Acer mono). It is suggested that the species-specific regeneration traits contribute to the coexistence of the four dominant species through different regeneration niches.

\section{Acknowledgements}

This study was partially supported by grants from the Ministry of Education, Culture, Sports, Science and Technology, Japan.

\section{References}

[1] Tatewaki, M. (1958) Forest Ecology of the Islands of the North Pacific Ocean. Journal of Faculty of Agriculture, Hokkaido University, 50, 371-486.

[2] Taylor, A.H. and Qin, Z. (1988) Regeneration Patterns in Old-Growth Abies-Betula Forests in the Wolong Natural Reserve, Sichuan, China. Journal of Ecology, 76, 1204-1218. https://doi.org/10.2307/2260643

[3] Ishikawa, Y., Krestov, P.V. and Namikawa, K. (1999) Disturbance History and Tree Establishment in Old-Growth Pinus koraiensis-Hardwood Forests in the Russian Far East. Journal of Vegetation Science, 10, 439-448. https://doi.org/10.2307/3237178

[4] Ishikawa, Y. and Ito, K. (1989) The Regeneration Process in a Mixed Forest in Central Hokkaido, Japan. Vegetatio, 79, 75-84. https://doi.org/10.1007/BF00044850

[5] Osawa, A. (1992) Development of a Mixed-Conifer Forest in Hokkaido, Northern Japan, Following a Catastrophic Windstorm: A "Parallel" Model of Plant Succession. In: Kelty, M.J., Larson, B.C. and Oliver, C.D., Eds., The Ecology and Silviculture of Mixed-Species Forests, Kluwer Academic Publisher, Dordrechtpp, 29-52. https://doi.org/10.1007/978-94-015-8052-6_3

[6] Oliver, C.D. and Stephens, E.P. (1977) Reconstruction of a Mixed-Species Forest in Central New England. Ecology, 58, 562-572. https://doi.org/10.2307/1939005

[7] Yamamoto, S., Nishimura, N. and Matsui, K. (1995) Natural Disturbance and Tree Species Coexistence in an Old-Growth Beech-Dwarf Bamboo Forest, Southwestern Japan. Journal of Vegetation Science, 6, 875-886. https://doi.org/10.2307/3236402

[8] Abrams, M.D. and Orwig, D.A. (1996) A 300-Year History of Disturbance and Canopy Recruitment for Co-Occurring White Pine and Hemlock on the Allegheny Plateau, USA. Journal of Ecology, 84, 353-363. https://doi.org/10.2307/2261198

[9] Takahashi, K., Mitsuishi, D., Uemura, S., Suzuki, J. and Hara, T. (2003) Stand Structure and Dynamics during a 16-Year Period in a Sub-Boreal Conifer-Hardwood Mixed Forest, Northern Japan. Forest Ecology and Management, 174, 39-50. https://doi.org/10.1016/S0378-1127(02)00018-X

[10] Lorimer, C.G. (1977) The Presettlement Forest and Natural Disturbance Cycle of Northeastern Maine. Ecology, 58, 139-148. https://doi.org/10.2307/1935115

[11] Canham, C.D. and Loucks, O.L. (1984) Catastrophic Windthrow in the Presettlement Forests of Wisconsin. Ecology, 65, 803-809. https://doi.org/10.2307/1938053

[12] Whitney, G.G. (1990) The History and Status of the Hemlock-Hardwood Forests of the Allegheny Plateau. Journal of Ecology, 78, 443-458.

https://doi.org/10.2307/2261123 
[13] Welden, C.W., Hewettt, S.W., Hubbell, S.P. and Foster, R.B. (1991) Sapling Survival, Growth, and Recruitment: Relationship to Canopy Height in a Neotropical Forest. Ecology, 72, 35-50. https://doi.org/10.2307/1938900

[14] Takahashi, K. (1996) Plastic Response to Crown Architecture to Crowding in Understorey Trees of Two Co-Dominating Confers. Annals of Botany, 77, 159-164. https://doi.org/10.1006/anbo.1996.0018

[15] Umeki, K. and Kikuzawa, K. (1999) Long-Term Growth Dynamics of Natural Forests in Hokkaido, Northern Japan. Journal of Vegetation Science, 10, 815-824. https://doi.org/10.2307/3237306

[16] He, F. and Duncan, R.P. (2000) Density-Dependent Effects on Tree Survival in an Old-Growth Douglas-Fir Forest. Journal of Ecology, 88, 676-688. https://doi.org/10.1046/j.1365-2745.2000.00482.x

[17] Wolf, A. (2005) Fifty Year Record of Change in Tree Spatial Patterns within a Mixed Deciduous Forest. Forest Ecology and Management, 215, 212-223. https://doi.org/10.1016/j.foreco.2005.05.021

[18] Kobe, R.K., Pacala, S.W., Silander, J.A. and Canham, C.D. (1995) Juvenile Tree Survivorship as a Component of Shade Tolerance. Ecological Applications, 5, 517-532. https://doi.org/10.2307/1942040

[19] Brokaw, N.V.L. (1985) Treefalls, Regrowth, and Community Structure in Tropical Forests. In: Pickett, S.T.A. and White, P.S., Eds., The Ecology of Natural Disturbance and Patch Dynamics, Academic Press, New York, 53-69.

[20] Whitmore, T.C. (1989) Canopy Gaps and the Two Major Groups of Forest Trees. Ecology, 70, 536-538. https://doi.org/10.2307/1940195

[21] Takahashi, K. (2010) Mid-Successional Stand Dynamics in a Cool-Temperate Conifer-Hardwood Forest in Northern Japan. Plant Ecology, 211, 159-5169. https://doi.org/10.1007/s11258-010-9781-2

[22] Kohyama, T. (1992) Size-Structured Multi-Species Model of Rain Forest Trees. Functional Ecology, 6, 206-212. https://doi.org/10.2307/2389756

[23] Kohyama, T. (1993) Size-Structured Tree Populations in Gap-Dynamic Forest: The Forest Architecture Hypothesis for the Stable Coexistence of Species. Journal of Ecology, 81, 131-143. https://doi.org/10.2307/2261230

[24] Hara, T., Nishimura, N. and Yamamoto, S. (1995) Tree Competition and Species Coexistence in a Cool-Temperate Old-Growth Forest in Southwestern Japan. Journal of Vegetation Science, 6, 565-574. https://doi.org/10.2307/3236355

[25] Nakashizuka, T. and Kohyama, T. (1995) The Significance of the Asymmetric Effect of Crowding for Coexistence in a Mixed Temperate Forest. Journal of Vegetation Science, 6, 509-516. https://doi.org/10.2307/3236349

[26] Takahashi, K. and Kohyama, T. (1999) Size-Structure Dynamics of Two Conifers in Relation to Understorey Dwarf Bamboo: A Simulation Study. Journal of Vegetation Science, 10, 833-842. https://doi.org/10.2307/3237308

[27] Monserud, R.A. and Sterbra, H. (1999) Modeling Individual Tree Mortality for Austrian Forest Species. Forest Ecology and Management, 113, 109-123. https://doi.org/10.1016/S0378-1127(98)00419-8

[28] Caspersen, J.P. and Kobe, R.K. (2001) Interspecific Variation in Sapling Mortality in Relation to Growth and Soil Moisture. Oikos, 92, 160-168. https://doi.org/10.1034/j.1600-0706.2001.920119.x

[29] Umeki, K. (2002) Tree Mortality of Five Major Species on Hokkaido Island, Northern Japan. Ecological Research, 17, 575-589. 
https://doi.org/10.1046/j.1440-1703.2002.00516.x

[30] Kunstler, G., Curt, T., Bouchaud, M. and Lepart, J. (2005) Growth, Mortality, and Morphological Response of European Beech and Downy Oak along a Light Gradient in Sub-Mediterranean Forest. Canadian Journal of Forest Research, 35, 1657-1668. https://doi.org/10.1139/x05-097

[31] Sokal, R.R. and Rohlf, F.J. (1981) Biometry. W. H. Freeman and Company, New York.

[32] Takahashi, K. (1997) Regeneration and Coexistence of Two Subalpine Conifer Species in Relation to Dwarf Bamboo in the Understorey. Journal of Vegetation Science, 8, 529-536. https://doi.org/10.2307/3237203

[33] Kikuzawa, K. (1983) Leaf Survival of Woody Plants in Deciduous Broad-Leaved Forests. 1. Tall Trees. Canadian Journal of Botany, 61, 2133-2139. https://doi.org/10.1139/b83-230

[34] Nascimento, H.E.M., Laurance, W.F., Condit, R., Laurance, S.G., D’Angelo, S. and Andrade, A.C. (2005) Demography and Life-History Correlates for Amazonian Trees. Journal of Vegetation Science, 16, 625-634. https://doi.org/10.1111/j.1654-1103.2005.tb02405.x

[35] King, D.A., Davies, S.J., Tan, S. and Noor, N.S.M. (2006) The Role of Wood Density and Stem Support Costs in the Growth and Mortality of Tropical Trees. Journal of Ecology, 94, 670-680. https://doi.org/10.1111/j.1365-2745.2006.01112.x

[36] Kullman, L. (1991) Structural Change in a Subalpine Birch Woodland in North Sweden during the Past Century. Journal of Biogeography, 18, 53-62. https://doi.org/10.2307/2845244

[37] Ohkubo, T. (1992) Structure and Dynamics of Japanese Beech (Fagus japonica Maxim.) Stools and Sprouts in the Regeneration of the Natural Forests. Vegetatio, 101, 65-80. https://doi.org/10.1007/BF00031916

[38] Takahashi, K., Homma, K., Vetrova, V.P., Florenzev, S. and Hara, T. (2001) Stand Structure and Regeneration in a Kamchatka Mixed Boreal Forest. Journal of Vegetation Science, 12, 627-634. https://doi.org/10.2307/3236902

[39] Hett, J.M. and Loucks, O.L. (1976) Age Structure Models of Balsam Fir and Eastern Hemlock. Journal of Ecology, 64, 1029-1044. https://doi.org/10.2307/2258822

[40] Takahashi, K., Seino, T. and Kohyama, T. (2001) Responses to Canopy Openings in Architectural Development of Saplings in Eight Deciduous Broad-Leaved Tree Species. Canadian Journal of Forest Research, 31, 1336-1347.

https://doi.org/10.1139/x01-069 